\title{
Production and Evaluation of Biscuits Made From Wheat Flour and Toasted Watermelon Seed Meal as Fat Substitute
}

\author{
A. I. Peter-Ikechukwu ${ }^{1}$, G. C. Omeire ${ }^{1}$, N. O. Kabuo ${ }^{1}$, C. N. Eluchie $^{1}$, C. Amandikwa ${ }^{1}$ \& G. I. Odoemenam ${ }^{1}$ \\ ${ }^{1}$ Department of Food Science and Technology, Federal University of Technology, Owerri, Nigeria \\ Correspondence: A. I. Peter-Ikechukwu, Department of Food Science and Technology, Federal University of \\ Technology, Owerri, Nigeria. E-mail: annadurunna@yahoo.com
}

Received: October 15, 2017

Accepted: November 3, 2017 Online Published: September 10, 2018

doi:10.5539/jfr.v7n5p112

URL: https://doi.org/10.5539/jfr.v7n5p112

\begin{abstract}
Production and evaluation of biscuits made from wheat flour and toasted watermelon seed meal as fat substitute was studied. Extracted watermelon seeds were toasted and grounded into seed meal, which were later used to formulate composite flour blends in the ratio of 10:90 $\left(\mathrm{MW}_{1}\right), 20: 80\left(\mathrm{MW}_{2}\right), 30: 70\left(\mathrm{MW}_{3}\right), 40: 60\left(\mathrm{MW}_{4}\right)$ and 50:50 $\left(\mathrm{MW}_{5}\right)$ of water melon seed meal: wheat flour respectively, while $100 \%$ wheat flour served as control $\left(\mathrm{W}_{1}\right)$. Each blend was used to produce biscuits adopting robbing process. The functional properties of flour blends, proximate composition and physical properties of the biscuit samples were determined. Sensory qualities of the biscuits were evaluated by 20 panelists. The accepted composite biscuit samples were stored on a shelf for 6 weeks and analyzed for moisture and total viable count. Data obtained were analyzed statistically $(\mathrm{P} \leq 0.05)$ for ANOVA, and means separated using Fisher's LSD Test. The results of the functional properties showed variations in behaviour. There were no significant differences $(\mathrm{P} \leq 0.05)$ in $\mathrm{pH}$, swelling index, viscosity and gelation temperature of the flour blends while significant differences ' $(\mathrm{P} \leq 0.05)$ existed in bulk density, water absorption capacity and wetability. There were significant differences $(\mathrm{P} \leq 0.05)$ in protein, fat, crude fibre, ash and carbohydrate for both flour blends and biscuit samples respectively. The addition of toasted watermelon seed meal increased protein, fat, crude fibre and ash contents while carbohydrate content decreased with higher substitution levels of wheat flour with the toasted watermelon seed meal. Moisture content ranged from 10-11\% (flour) and $6.25-10 \%$ (biscuit). Significant differences $(\mathrm{P} \leq 0.05)$ were recorded in thickness, spread ratio and break strength within the samples. The result of sensory evaluation showed that $\mathrm{W}_{1}$ was significantly different $(\mathrm{P} \leq 0.05)$ in taste, aroma and overall acceptance.
\end{abstract}

However, $\mathrm{MW}_{4}$ and $\mathrm{MW}_{5}$ were significantly different in texture, but in terms of crispiness, $\mathrm{MW}_{1}$ and $\mathrm{MW}_{3}$ were preferred. Moisture content of the preferred samples $\left(\mathrm{MW}_{1}\right.$ and $\left.\mathrm{MW}_{3}\right)$ stored for 6 weeks increased from $6.25-11.75 \%\left(\mathrm{MW}_{1}\right)$ and $6.75-11.0 \%\left(\mathrm{MW}_{3}\right)$ while the viable microbial counts ranged from $2.0 \times 10^{2}-6.8 \times$ $10^{5} \mathrm{cfu} / \mathrm{g}$ for bacteria and $1.8 \times 10^{1}-7.4 \times 10^{3} \mathrm{cfu} / \mathrm{g}$ for mould respectively.

Keywords: wheat flour, watermelon seeds, biscuits, acceptability, moisture

\section{Introduction}

The consumption of cereal snack foods such as biscuits (also known as cookies), wafers and short bread has become very popular especially among children. Biscuits possess several attractive features including wider consumption base, relatively long shelf life and good eating quality (Banureka and Mahendran, 2009).

Biscuit and biscuit-like products have been made and eaten by man for many hundreds if not thousands of years and their good eaten quality makes them attractive for protein fortification and nutritional improvements, particularly in children feeding programmes, for the elderly and low income groups (Banureka and Mahendran, 2009).

Wheat flour is the main ingredient for biscuit production, though imported; it is a carbohydrate based food raw material and also lack some nutrients.

Composite flour has been defined as a mixture of different ratios of non-wheat flour from cereals, legumes, roots and tubers with or without wheat flour. In many countries, biscuits are prepared with fortified or composite flour to increase their nutritive value (Hasmadi et al., 2014). Enrichment of cereal-based foods with other protein sources such as oilseeds and legumes has received considerable attention (Ayo and Olawale, 2003). This is 
because oilseeds and legume proteins are high in lysine- an essential limiting amino acid in most cereals including wheat (Banureka and Mahendran, 2009). The usefulness of grain-oilseeds in developing high protein foods in meeting the needs of the vulnerable group of the population is now well recognized, and several high protein-energy foods have been developed industrially in different parts of the world (Mooriya, 2003).

Watermelon (Citrullus lanatus) is a typical fruit from the family of cucurbitaceae grown in the warmer part of the world whose seeds are underutilized. The seeds are rich source of dietary fibre, $(5 \%)$ high in protein (35\%) and fat $(50 \%)$, it is a rich source of magnesium, calcium, potassium, iron, phosphorus and zinc (Odibo et al., 2012) and with excellent functional properties which have been found to be effective in baking (El-Adawy and Taha, 2001).

Water melon seeds are known to be highly nutritional: they are rich sources of protein, B vitamins, Minerals (such as magnesium, potassium, phosphorus, sodium, iron, zinc, manganese and copper) and fat among others as well as phytochemicals (Braide et al., 2012), Water melon seeds are rich for strong bones and teeth as well as hemoglobin formation. Fat in a biscuit formulation has a multifaceted function. It is the principal ingredient responsible for tenderness, eaten quality, keeping quality, grain and texture, and adding richness to biscuits (O'brien, 2003). The food industry is primarily driven by consumer health trends. A present day dietary concern is the consumption of fat and sugar, which have been found to be associated with an increase in the incidence of obesity and related health problems, including coronary heart disease (CHD) (Boobier et al., 2006).

Biscuits have previously been highlighted in a report by Willet et al (1993) as being significantly associated with an increased risk of CHD. Nisbett et al (1986) noted that biscuit market is dominated by short dough biscuits having fat levels in excess of 20\%. However, Mensink and Katan (1987) stated that the replacement of saturated or trans- unsaturated fat with unhydrogenated unsaturated fats is associated with larger reductions in risk factors associated with CHD.

The aim of this work therefore is to produce biscuits from blends of wheat flour and toasted watermelon seeds for fat substitution.

\section{Materials and Methods}

\subsection{Material Procurement}

Watermelon fruits, wheat, sugar, margarine, milk powder, baking powder, salt, egg and vanilla powder were purchased from Owerri main market, Imo State, Nigeria.

\subsection{Methods}

\subsubsection{Production of Watermelon Seed Flour}

Toasted watermelon seed flour was prepared by deseeding watermelon pods, the brown seeds were washed (with potable water), drained and sun dried. The seeds were toasted in a shallow pan at $130^{\circ} \mathrm{C}$ for 20 minutes, cooled, milled with harmer mill and sieved through 60 mesh sieve to obtain a fine flour. The watermelon seed flour was sealed in a cellophane bag and stored at room temperature $\left(25^{\circ} \mathrm{C}\right)$ for further use. The modified method of Ubbor and Akobundu (2009) as shown in (figure 1) was used in the production of toasted watermelon seed flour. 


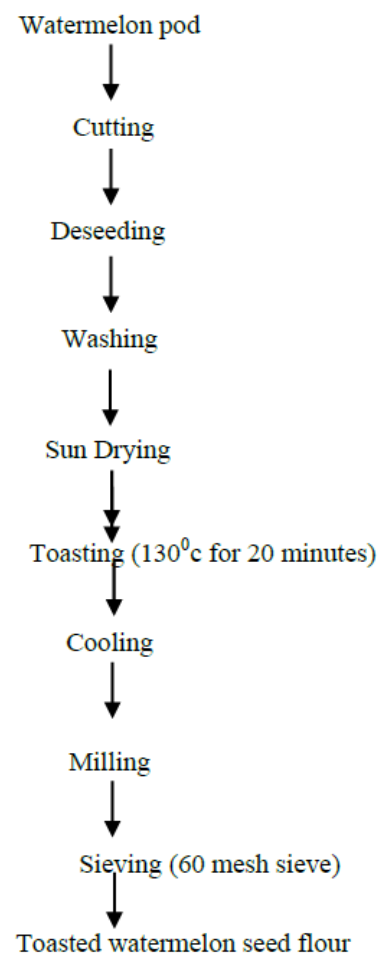

Figure 1. Flow diagram of toasted watermelon seed flour production

\subsubsection{Formulation of Flour Blend}

Five blends were prepared by mixing toasted whole watermelon seed flour with wheat flour using an electric blender in the percentage ratio of 10:90,20:80,30:70,40:60 and 50:50 respectively while hundred percent(100\%) wheat flour served as the control.

Table 1. Formulation of flour blend

\begin{tabular}{lll}
\hline Blends & Toasted watermelon seed flour (\%) (M) & Wheat flour $(\%)(W)$ \\
\hline$W_{1}$ & - & 100 \\
$M_{1}$ & 10 & 90 \\
$M_{2}$ & 20 & 80 \\
$M_{3}$ & 30 & 70 \\
$M_{4}$ & 40 & 60 \\
$M_{5}$ & 50 & 50 \\
\hline
\end{tabular}

\subsubsection{Biscuit Preparation}

Biscuits were prepared according to the method of AOAC (2000) with some modifications in the recipe. The dry ingredients (flour, sugar, salt, and baking powder) were thoroughly mixed in a bowl by hand for $3 \mathrm{~min}$. Egg and water were then added and the mixture kneaded. The batter was rolled and cut with a biscuit cutter. The cut dough was placed on oil greased baking trays, leaving $25 \mathrm{~mm}$ spaces in between and was baked at $200^{\circ} \mathrm{C}$ for $25 \mathrm{~min}$ in the baking oven. Following baking, the biscuits were cooled at ambient temperature, packed in polyethylene chin-chin bags and stored at near ambient temperature $\left(28 \pm 2^{\circ} \mathrm{C}\right)$ prior to subsequent analysis and sensory evaluation. Ingredients used for biscuit making were flour (200g), sugar (60g), milk poweder (30g), egg $(30 \mathrm{~g})$, baking powder $(1.5 \mathrm{~g})$, salt $(1.5 \mathrm{~g})$, vanilla powder (4 drops), water $(15 \mathrm{ml})$, while $80 \mathrm{~g}$ of magarine was added to the control only. The procedure is shown in Figure 2. 


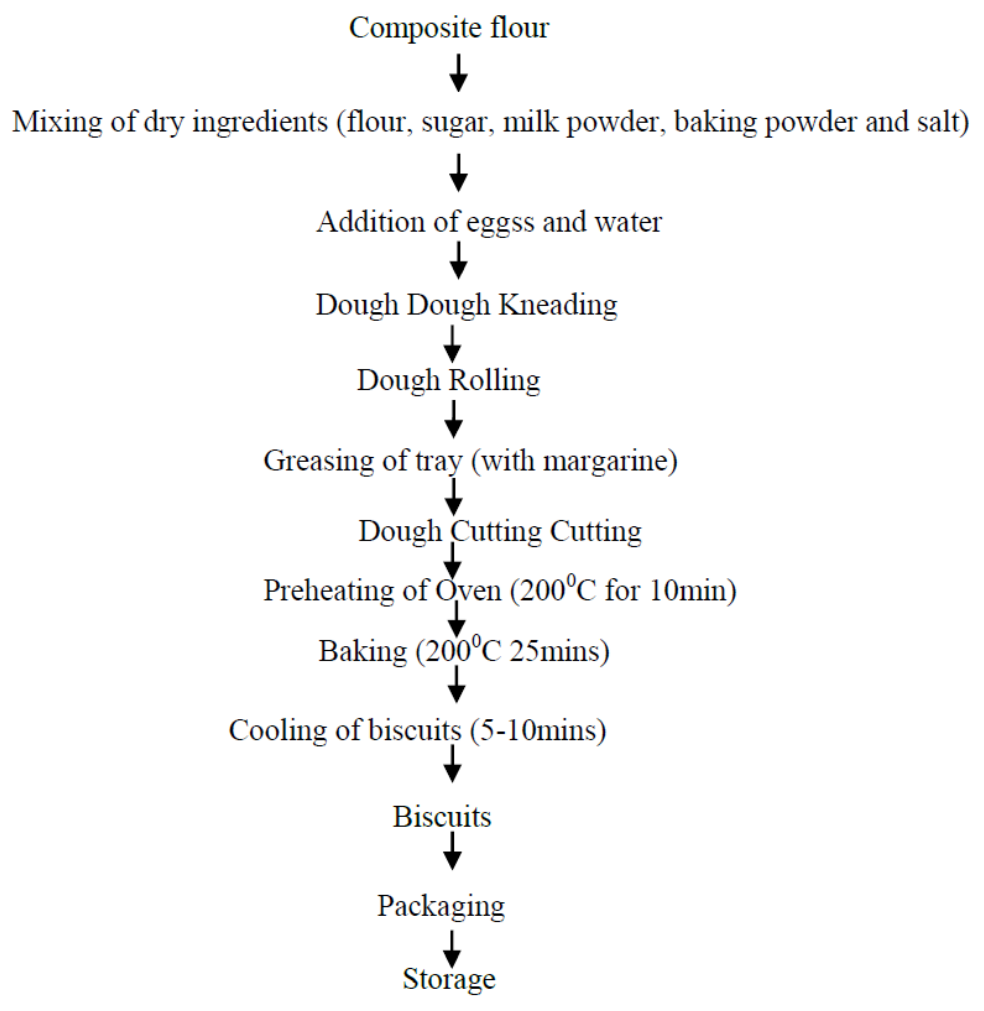

Figure 2. Flow diagram for wheat/watermelon flour biscuit production

\subsubsection{Determination of Functional Properties}

Bulk density, $\mathrm{pH}$,emulsion capacity, wettability, viscosity, water absorption capacity, oil absorption capacity, swelling index and gelation temperature were analyzed as described by Onwuka (2005) and Ukpabi and Ndimele (1990).

\subsubsection{Determination of Proximate Composition}

Moisture content, ash content, crude fat, crude protein, crude fibre and carbohydrate content of the flour sample were carried out using $\mathrm{AOAC}(2000)$ methods.

\subsubsection{Physical Analysis of Biscuits Produced}

The weight and diameter of the baked biscuit were determined by weighing on a weighing balance and measuring with a calibrated ruler, respectively (Ayo et al, 2007). The thickness was measured according to AOAC method 10-50D (AOAC, 2000). The spread ratio was determined using the method of Gomez et., al. (1997). Three rows of five well-formed biscuit were made and the height measured. Also the same were arranged horizontally edge to edge and sum diameter measured. The spread ratio was calculated as diameter/ height. The break strength of the biscuit was determined according to Okaka and Isieh (1990) method. Biscuit of known thickness $(0.4 \mathrm{~cm})$ was placed between two parallel wooden bars $(3.0 \mathrm{~cm}$ apart). Weights were added on the biscuit until the biscuit snapped. The least weight that caused the breaking of the biscuit was regarded as the break strength of the biscuit.

\subsubsection{Sensory Evaluation}

Sensory evaluations of the biscuits were determined using twenty-member panelist consisting of staff and students of the Department of Food Science and Technology, Federal University of Technology, Owerri, Nigeria. The panelists were either regular or occasionally consumers of biscuits and were not allergic to any food. Biscuits samples prepared from each flour blend were presented in coded white microwavable plastic container. The order of presentation of samples to the panelists was randomized. Sachet water was provided to rinse the mouth between evaluations. The panelists were instructed to evaluate the coded samples for taste, aroma, colour, texture, crispiness and overall acceptability. Each sensory attribute was rated on a 9-point Hedonic scale (for taste, aroma and overall acceptability, $1=$ disliked extremely, $5=$ neither like nor dislike, while $9=$ liked extremely. For colour, $1=$ extremely white, $5=$ neither brown nor white, while $9=$ extremely brown. For texture: 
$1=$ extremely marshy, $5=$ neither strong nor soft, while $9=$ extremely strong and firm. And for crispiness, $1=$ extremely soft and mealy, $5=$ neither crispy nor soft, while $9=$ extremely crispy and grainy) (Ihekoronye and Ngoddy, 1985).

\subsubsection{Microbiological Analysis of Biscuits Produced}

Total viable bacteria counts and fungi counts (yeasts and moulds) were carried out on biscuit samples to determine the microbial load of the samples as described by Roberts and Greenwood, 2003. One (1g) gram of each biscuit sample was prepared by mashing and mixing in $9 \mathrm{ml}$ of distilled water. Serial dilutions up to $10^{-9}$ were carried out and $0.1 \mathrm{ml}$ each was poured in the nutrient agar (NA) media petri dish, and potato dextrose agar (PDA) petri dish for the enumeration of aerobic viable bacteria and fungi respectively. The NA petri dishes were incubated at the temperature of $37^{\circ} \mathrm{C}$ for $24-48$ hours while PDA petri dishes were incubated at $30^{\circ} \mathrm{C}$ for up to 5 days. The colonies were then counted and expressed as colony forming units per gram (cfu/g) of samples.This was done on Weeks 1,3 and 6 of storage periods.

\section{Results and Discussion}

\subsection{Functional properties}

The result of the functional properties of the flour blends are shown in Table (2). $\mathrm{pH}$ of the flour samples ranged from 6.528 to $6.670 . \mathrm{MW}_{5}$ had the highest value (6.670) while $\mathrm{W}_{1}$ had the least (6.528). There was no significant difference, however, $\mathrm{pH}$ increased with higher substitution with toasted watermelon seed meal. The $\mathrm{pH}$ values of the flour samples were $>6.5$ being considered non acidic food product.

Table 2. Functional properties of the flour blends

\begin{tabular}{|c|c|c|c|c|c|c|c|c|c|}
\hline Sample M:W & $\mathrm{pH}$ & $\mathrm{BD}(\mathrm{g} / \mathrm{ml})$ & WAC $(\mathrm{g} / \mathrm{g})$ & $\mathrm{OAC}(\mathrm{g} / \mathrm{g})$ & $\mathrm{SI}(\mathrm{ml})$ & $\mathrm{EC}(\%)$ & Wet $(\mathrm{Sec})$ & Viscosity (\%|) & Gelation temp $\left({ }^{\circ} \mathrm{C}\right)$ \\
\hline $\mathrm{W}_{1}$ & $6-528 \pm 0.05$ & $0.796^{\mathrm{a}} \pm 0.00$ & $1.217^{\mathrm{d}} \pm 0.00$ & $1.454^{\mathrm{cd}} \pm 0.02$ & $1.056+0.08$ & $1.987 \pm 0.02$ & $51.00^{\mathrm{a}} \pm 6.48$ & $5.80 \pm 0.98$ & $67 \pm 2.45$ \\
\hline $\mathrm{MW}_{1}$ & $6.619 \pm 0.04$ & $0.771^{\mathrm{b}} \pm 0.07$ & $1.213^{\mathrm{d}} \pm 0.00$ & $1.626^{\mathrm{b}} \pm 0.03$ & $0.875 \pm 0.09$ & $2.000 \pm 0.00$ & $34.00^{\mathrm{b}} \pm 3.27$ & $5.95 \pm 0.20$ & $63.67 \pm 2.87$ \\
\hline $\mathrm{MW}_{3}$ & $6.650 \pm 0.04$ & $0.789^{\mathrm{a}} \pm 0.02$ & $1.280^{6} \pm 0.01$ & $1.389^{\mathrm{d}} \pm 0.08$ & $0.786 \pm 0.01$ & $2.033 \pm 0.00$ & $28.67^{\mathrm{b}} \pm 1.89$ & $6.35 \pm 1.10$ & $63 \pm 0.82$ \\
\hline $\mathrm{MW}_{4}$ & $6.667 \pm 0.04$ & $0.717^{\mathrm{C}} \pm 0.07$ & $1.303^{\mathrm{b}} \pm 0.00$ & $1.626^{\mathrm{b}} \pm 0.03$ & $0.774 \pm 0.06$ & $1.973 \pm 0.04$ & $16.00^{\mathrm{C}} \pm 1.63$ & $5.85 \pm 1.43$ & $61 \pm 2.45$ \\
\hline $\mathrm{MW}_{5}$ & $6.670 \pm 0.05$ & $0.771^{\mathrm{b}} \pm 0.00$ & $1.357^{\mathrm{a}} \pm 0.00$ & $1.531^{\mathrm{C}_{ \pm 0}} .04$ & $0.758 \pm 0.06$ & $2.000 \pm 0.00$ & $12.00^{\mathrm{C}} \pm 1.41$ & $6.15 \pm 0.61$ & $62 \pm 1.63$ \\
\hline
\end{tabular}

Where $\mathrm{pH}=$ Hydrogen ion concentration, $\mathrm{BD}=$ Bulk density, WAC $=$ Water absorption capacity, $\mathrm{OAC}=$ Oil absorption capacity, $\mathrm{SI}=\mathrm{Swelling}$ index, $\mathrm{EC}=$ Emulsion capacity, Wet =wettability.

Mean \pm Standard deviation of triplicate determination

Means with the same superscripts within a column are not significantly different $(\mathrm{P}<0.05)$

$\mathrm{W}_{1}=$ Wheat flour $(100 \%)$

$\mathrm{MW}_{1}=$ watermelon seed meal/Wheat flour (10:90)

$\mathrm{MW}_{2}=$ Watermelon seed meal/wheat flour (20:80)

$\mathrm{MW}_{3}=$ Watermelon seed meal/wheat flour (30:70)

$\mathrm{MW}_{4}=$ Watermelon seed meal/Wheat flour (40:60)

$\mathrm{MW}_{5}=$ Watermelon seed meal/ wheat flour (50:50)

$\mathrm{W}_{1}$ and $\mathrm{MW}_{2}$ were not significantly different. WAC is the ability of a product to associate with water under limiting condition (Singh, 2001). Water absorption capacity (WAC) was found to be higher in $\mathrm{MW}_{5}(1.357 \mathrm{~g} / \mathrm{g}$ ) while $\mathrm{MW}_{1}$ had the least $(1.213 \mathrm{~g} / \mathrm{g})$. Significant difference $(\mathrm{P} \leq 0.05)$ existed within the samples. $\mathrm{W}_{1}$ and $\mathrm{MW}_{2}$ were not significantly different. Obasi et al (2012), reported that the water absorption capacity of wheat flour was $2.04 \mathrm{~g} / \mathrm{g}$ which was higher than the value obtain in this work $(1.217-1.357 \mathrm{~g} / \mathrm{g})$. This could be due to variation in cultivar, location of cultivation etc. It has been suggested that flours with high WAC will be very useful in bakery products as this could prevent staling by reducing moisture loss (Obatolu et al., 2007).

Oil Absorption Capacity (OAC) values ranged from $1.389 \mathrm{~g} / \mathrm{g}$ to $1.812 \mathrm{~g} / \mathrm{g}$. Significant difference $(\mathrm{p} \leq 0.05$ ) occurred among the flour samples. $\mathrm{MW}_{2}$ was significantly different from the rest. Oil absorption capacity increased with increase in level of substitution from $\mathrm{W}_{1}-\mathrm{MW}_{2}(1.454 \mathrm{~g} / \mathrm{g}$ to $1.812 \mathrm{~g} / \mathrm{g})$. The oil absorption capacity of the flour blends suggests that they may be useful in food preparation that involves mixing like bakery products where oil is an important ingredient. The oil absorption capacity of the flour blends increased with increase in protein content since the protein in foods influences fat absorption. OAC is the ability of flour to absorb oil, oil act as flavour retainer, and improves mouth feel .This shows that sample $\mathrm{MW}_{2}$ could retain the biscuit flavour.

There was no significant difference $(\mathrm{p} \leq 0.05)$ among the flour samples in swelling index, however, the values 
ranged from $0.758 \mathrm{ml}$ to $1.056 \mathrm{ml} . \mathrm{W}_{1}$ had the highest swelling index while $\mathrm{MW}_{5}$ had the lowest. Observation indicated that swelling index decreased with higher substitution with toasted watermelon seed meal and could be due to higher protein content in watermelon seed meal. The presence of protein bodies around starch granules (due to increased protein content) may restrict granule swelling and hence, reduce the susceptibility to enzymatic attack.

Emulsion Capacity (EC) values ranged from 1.973 to 2.033. This is suggesting that the flour blends may be good emulsifying agent. Increase in protein content with increase in substitution level aid in formulation and stabilization of emulsion (Abbey et al., 1998). There was no significant difference among the flour samples. Emusion capacity denotes the maximum amount of oil that can be emulsified by flour dispersion (Oluwalana and Oluwamukami, 2011). Brandt (1996), reported that emulsifiers help retard staling in baked goods, thereby prolonging shelf life. Wettability decreased with increased in substitution. $\mathrm{W}_{1}$ had the highest $(51 \mathrm{sec})$ while $\mathrm{MW}_{5}$ had the lowest $(12 \mathrm{sec})$. Significant difference $(\mathrm{p} \leq 0.05)$ occurred among the samples. $\mathrm{W}_{1}$ was significantly different from the rest. According to Oti and Akobundu (2008), the lower the level of denatured protein in the starch the slower it takes to get wetted or imbibe water.

No significant difference occurred in viscosity among the flour samples, however, $\mathrm{MW}_{3}$ had the highest value $(6.35 \%)$ while $\mathrm{MW}_{2}$ had the least (4.95\%). Viscosity is an indication of viscous load (opposition to flow) likely to be encountered during mixing (Maziya-Dixon et al., 2007).

Gelation temperature value was highest in $\mathrm{W}_{1}\left(67^{\circ} \mathrm{C}\right)$ while $\mathrm{MW}_{4}$ had the least $\left(61^{\circ} \mathrm{C}\right)$ though there was no significant difference among the samples. Gels primarily enhance the body and texture of a food product.

\subsection{Proximate Composition}

The results for proximate composition of flour blends and biscuit samples are shown in Table (3) and (4) respectively. Moisture, protein, fat, ash and carbohydrate contents of the flour samples ranged from $10-11 \%$, $14.15-23.25 \%, 1.25-9.25 \%, 1.3-4.18 \%, 1.6-3.55 \%$ and $49.77-70.70 \%$ respectively. The moisture content of $\mathrm{W}_{1}(11 \%)$ was highest while the rest samples were below $11 \%$. No significant difference was observed among the flour samples even though addition of toasted watermelon seed meal decreased the moisture content. The moisture contents of the composite flours were slightly above moisture level (below 10\%) recommended for safe keeping of flour samples. Moisture content of biscuit samples range from $6.25-10.00 \% . \mathrm{MW}_{5}$ had the highest value, followed by $\mathrm{MW}_{2}$ even though there was no significant difference among the samples. The highest value obtained in $\mathrm{MW}_{5}$ could be due to variation in the oven heat distribution. Smith (1972), established that total moisture content for biscuits should not exceed $14 \%$ and that $5 \%$ is the best. Therefore, the moisture contents of the biscuits were within the acceptable level.

$\mathrm{MW}_{5}$ had the highest value in protein, fat, crude fibre, and ash contents for the flour samples, while $\mathrm{W}_{1}$ had the least. There were significant differences $(\mathrm{p} \leq 0.05)$ among the flour samples in the parameters mention above. $\mathrm{W}_{1}$ and $\mathrm{MW}_{5}$ were each significantly different from the rest of the samples respectively. Protein, fat, crude fibre, and ash contents increased with higher substitution with toasted watermelon seed meal. This is expected as watermelon seed is high in protein, fat (oil), crude fibre and ash (El-Adawy and Taha, 2001).

Table 3. Proximate Composition of the flour blends from toasted watermelon seed meal (M) and wheat flour (W)

\begin{tabular}{lllllll}
\hline Flour blends & Moisture $(\%)$ & Protein $(\%)$ & Fat $(\%)$ & Crude fibre $(\%)$ & Ash $(\%)$ & Carbohydrate $(\%)$ \\
\hline $\mathrm{W}_{1}$ & $11.00 \pm 0.00$ & $14.15^{\mathrm{e}} \pm 0.35$ & $1.25^{\mathrm{f}} \pm 0.25$ & $1.30^{\mathrm{f}} \pm 0.100$ & $1.60^{\mathrm{d}} \pm 000$ & $70.70^{\mathrm{a}} \pm 0.00$ \\
$\mathrm{MW}_{1}$ & $10.50 \pm 0.00$ & $18.11^{\mathrm{d}} \pm 0.10$ & $2.75^{\mathrm{e}} \pm 0.25$ & $1.77^{\mathrm{e}} \pm 0.015$ & $2.35^{\mathrm{c}} \pm 0.15$ & $64.52^{\mathrm{b}} \pm 0.01$ \\
$\mathrm{MW}_{2}$ & $10.75 \pm 0.25$ & $18.70^{\mathrm{d}} \pm 0.20$ & $4.60^{\mathrm{d}} \pm 0.00$ & $2.35^{\mathrm{d}} \pm 0.050$ & $2.60^{\mathrm{c}} \pm 0.10$ & $61.00^{\mathrm{c}} \pm 0.00$ \\
$\mathrm{MW}_{3}$ & $10.25 \pm 8.25$ & $19.33^{\mathrm{c}} \pm 0.08$ & $7.00^{\mathrm{c}} \pm 0.00$ & $3.15^{\mathrm{c}} \pm 0.050$ & $3.00^{\mathrm{b}} \pm 0.00$ & $57.27^{\mathrm{d}} \pm 0.01$ \\
$\mathrm{MW}_{4}$ & $10.00 \pm 0.50$ & $20.19^{\mathrm{b}} \pm 0.14$ & $8.00^{\mathrm{b}} \pm 0.00$ & $3.60^{\mathrm{b}} \pm 0.100$ & $3.25^{\mathrm{b}} \pm 0.05$ & $54.96^{\mathrm{e}} \pm 0.01$ \\
$\mathrm{MW}_{5}$ & $10.00 \pm 0.50$ & $23.25^{\mathrm{a}} \pm 0.10$ & $9.25^{\mathrm{a}} \pm 0.25$ & $4.18^{\mathrm{a}} \pm 0.025$ & $3.55^{\mathrm{a}} \pm 0.05$ & $49.77^{\mathrm{f}} \pm 0.01$ \\
LSD & - & 0.633 & 0.612 & 0.227 & 0.274 & 0.014 \\
\hline
\end{tabular}

Mean \pm SD of duplicate determination

Means with the same superscript in column are not significantly different $(\mathrm{P} \leq 0.05)$

$\mathrm{W}_{1}$ : Wheat flour $(100 \%)$

$\mathrm{MW}_{1}$ : Watermelon seed meal/wheat flour (20:80)

$\mathrm{MW}_{3}$ : Watermelon seed meal/wheat flour (30:70)

$\mathrm{MW}_{4}$ : Watermelon seed meal/ wheat flour (40:60)

$\mathrm{MW}_{5}$ : Watermelon seed meal/wheat flour (50:50) 
Table 4. Proximate Composition of the Biscuits Produced

\begin{tabular}{lllllll}
\hline Biscuits & Moisture $(\%)$ & Protein $(\%)$ & Fat $(\%)$ & Crude fibre $(\%)$ & Ash $(\%)$ & Carbohydrate $(\%)$ \\
\hline $\mathrm{W}_{1}$ & $6.50 \pm 0.50$ & $12.00^{\mathrm{e}} \pm 0.50$ & $23.25^{\mathrm{a}} \pm 0.25$ & $1.45^{\mathrm{a}} \pm 0.05$ & $1.79^{\mathrm{f}} \pm 0.02$ & $55.01^{\mathrm{e}} \pm 0.01$ \\
$\mathrm{MW}_{1}$ & $6.25 \pm 0.75$ & $15.25^{\mathrm{d}} \pm 0.25$ & $4.00^{\mathrm{f}} \pm 0.00$ & $2.30^{\mathrm{d}} \pm 0.10$ & $2.49^{\mathrm{e}} \pm 0.02$ & $69.71^{\mathrm{a}} \pm 0.01$ \\
$\mathrm{MW}_{2}$ & 7.67 & $17.25^{\mathrm{c}} \pm 0.25$ & $5.25^{\mathrm{e}} \pm 0.25$ & $3.55^{\mathrm{c}} \pm 0.25$ & $3.10^{\mathrm{d}} \pm 0.10$ & $60.85^{\mathrm{b}} \pm 0.01$ \\
$\mathrm{MW}_{3}$ & $6.75 \pm 1.25$ & $17.68^{\mathrm{c}} \pm 0.18$ & $8.25^{\mathrm{d}} \pm 0.25$ & $3.60^{\mathrm{c}} \pm 0.10$ & $3.50^{\mathrm{c}} \pm 0.10$ & $60.22^{\mathrm{c}} \pm 0.01$ \\
$\mathrm{MW}_{4}$ & $6.50 \pm 1.00$ & $19.25^{\mathrm{b}} \pm 0.25$ & $9.25^{\mathrm{c}} \pm 0.25$ & $4.20^{\mathrm{b}} \pm 0.10$ & $4.00^{\mathrm{b}} \pm 0.00$ & $56.80^{\mathrm{d}} \pm 0.00$ \\
$\mathrm{MW}_{5}$ & $7.75 \pm 0.25$ & $21.25^{\mathrm{a}} \pm 0.25$ & $11.25^{\mathrm{b}} \pm 0.25$ & $4.4^{\mathrm{b}} \pm 0.2$ & $4.60^{\mathrm{a}} \pm 0.05$ & $50.75^{\mathrm{f}} \pm 0.01$ \\
LSD & - & 1.029 & 0.790 & 0.519 & 0.213 & 0.016 \\
\hline
\end{tabular}

Mean \pm SD of duplicate determination

Means with the same superscript in column are not significantly different $(\mathrm{P} \leq 0.05)$

$\mathrm{W}_{1}$ : Wheat flour (100\%)

$\mathrm{MW}_{1}$ : Watermelon seed meal/wheat flour (20:80)

$\mathrm{MW}_{3}$ : Watermelon seed meal/wheat flour (30:70)

$\mathrm{MW}_{4}$ : Watermelon seed meal/wheat flour (40:60)

$\mathrm{MW}_{5}$ : Watermelon seed meal/wheat flour (50:50)

Proteins are the body's building blocks and foods that are rich in protein are known to reduce protein energy malnutrition. $\mathrm{MW}_{5}(21.25 \%)$ was highest in protein for the biscuit samples while $\mathrm{W}_{1}(12 \%)$ had the least. Significant difference $(\mathrm{p} \leq 0.05)$ occurred within the samples however, protein increased with increase in substitution.

Fat content of biscuit samples was found to be highest in $\mathrm{W}_{1}(23.25 \%)$ while $\mathrm{MW}_{1}(4 \%)$ was the least. Significant difference $(\mathrm{p} \leq 0.05)$ existed within the biscuits samples. However, fat increased with increase in substitution. Fat gives flavour and soft texture to foods; nevertheless, high levels of fat are undesirable in food products because they could lead to rancidity in foods (Ihekoronye and Ngoddy, 1985). Furthermore, eating foods rich in trans fats present in bakery fats create inflammation, which is linked to heart disease, stroke, diabetes, and other chronic health conditions (http://www.health.harvard.edu).

Crude fibre of biscuit samples was found to be highest in $\mathrm{MW}_{5}(4.4 \%)$ while $\mathrm{W}_{1}(1.45 \%)$ had the least. Significant difference $(\mathrm{p} \leq 0.05)$ occurred among the samples. The fibre contents of the biscuits were within the recommended range of not more than $5 \mathrm{~g}$ dietary fibre / 100g of dry matter (FAO/WHO, 1994).Dietary fibre has a protective action against various disorders such as diabetes mellitus, cardiovascular diseases, constipation, appendicitis, hemorrhoids, and colon cancer (Mervat, 2011; Bhawna et al., 2013).

Biscuit could enhance the intake of minerals, significant amount of vitamin C, minerals, fats, starch, and riboflavin have been obtained from water melon seed (Erhirhie and Ekene, 2013); as ash is an index to determine mineral constituents in food. Highest ash content of biscuit samples was found in $\mathrm{MW}_{5}(4.6 \%)$ while $\mathrm{W}_{1}(1.79)$ had the least. There was significant difference $(\mathrm{p} \leq 0.05)$ among the samples. This result showed increase in ash with higher substitution and could be attributed to addition of watermelon seed . Similar result was obtained by Ubbor and Akobundu (2009) from cookies produced from composite flour blends of watermelon seed flour/ wheat flour. Carbohydrate contents was highest $(70.70 \%)$ in $\mathrm{W}_{1}$, while $\mathrm{MW}_{5}(49.77 \%)$ had the least. Significant difference $(\mathrm{p} \leq 0.05)$ existed within the flour samples. The carbohydrate contents of composite flours decreased with increase in substitution and are similar to that observed from composite flour of unripe plantain/wheat/watermelon seed. The carbohydrate contents for biscuit samples ranged from $50.75-69.71 \%$. Significant different $(\mathrm{p} \leq 0.05)$ occurred within the samples. $\mathrm{MW}_{1}(69.71 \%)$ had the highest while $\mathrm{MW}_{5}(50.75 \%)$ had the least. However, carbohydrate contents of composite biscuit samples decreased according to higher substitution level.

\section{Physical Properties of biscuits:}

The results of the physical properties of the biscuit samples are shown in Table (5). Thickness, diameter, weight, spread ratio and break strength values ranged from $0.61-0.70 \mathrm{~cm}, 3.0-3.4 \mathrm{~cm}, 5.22-6.24 \mathrm{~cm}, 5.05-5.26$, and $1400-2995 \mathrm{~g}$ respectively. Thickness and spread ratio have inverse relation. $\mathrm{MW}_{3}(0.70)$ had the highest value in thickness while $\mathrm{MW}_{2}(0.61)$ had the least. Significant difference $(\mathrm{p} \leq 0.05)$ occurred among biscuit samples. $\mathrm{MW}_{2}$ and $\mathrm{MW}_{5}$ were each significantly different from the rest of the samples respectively.

Spread ratio was found to be highest in $\mathrm{MW}_{2}$ (5.26) while $\mathrm{MW}_{3}$ (5.05) had the least. Significant difference $(\mathrm{p} \leq 0.05)$ occurred within the samples. $\mathrm{W}_{1}$ and $\mathrm{MW}_{4}$ are not significantly different likewise $\mathrm{MW}_{1}, \mathrm{MW}_{3}$ and 
$\mathrm{MW}_{5} . \mathrm{MW}_{4}$ was significantly different from the rest of the samples. This result could be due to the dough viscosity as evidenced in viscosity of the flour blends (Table 5). According to Miller et al (1997), spread ratio is restricted by dough viscosity as dough with lower viscosity causes cookies to spread faster. Low spread ratio suggests that the starches in the cookies are very hydrophilic (Yahya, 2004; cited in Okpala and Egwu, 2015).

Table 5.Physical properties of Biscuits

\begin{tabular}{llllll}
\hline Sample & Thickness $(\mathrm{CM})$ & Diameter(CM) & Weight $(\mathrm{g})$ & Spread ratio(SR) & Break strength $(\mathrm{g})$ \\
\hline $\mathrm{W}_{1}$ & $0.66^{\mathrm{C}} \pm 0.01$ & $3.3 \pm 0.08$ & $6.24 \pm 0.81$ & $5.18^{\mathrm{b}} \pm 0.02$ & $1400^{\mathrm{f}} \pm 0.00$ \\
$\mathrm{MW}_{1}$ & $0.69^{\mathrm{b}} \pm 0.01$ & $3.2 \pm 0.05$ & $5.74 \pm 0.38$ & $5.07^{\mathrm{c}} \pm 0.02$ & $1975^{\mathrm{e}} \pm 20.41$ \\
$\mathrm{MW}_{2}$ & $0.61^{\mathrm{e}} \pm 0.01$ & $3.4 \pm 0.00$ & $6.01 \pm 0.45$ & $5.26^{\mathrm{a}} \pm 0.02$ & $2395^{\mathrm{d}} \pm 4.08$ \\
$\mathrm{MW}_{3}$ & $0.70^{\mathrm{a}} \pm 0.00$ & $3.0 \pm 0.05$ & $6.05 \pm 0.36$ & $5.05^{\mathrm{c}} \pm 0.04$ & $2645^{\mathrm{c}} \pm 4.08$ \\
$\mathrm{MW}_{4}$ & $0.65^{\mathrm{c}} \pm 0.02$ & $3.3 \pm 0.05$ & $5.42 \pm 0.42$ & $5.15^{\mathrm{b}} \pm 0.04$ & $2885^{\mathrm{b}} \pm 4.08$ \\
$\mathrm{MW}_{5}$ & $0.63^{\mathrm{d}} \pm 0.01$ & $3.1 \pm 0.08$ & $5.22 \pm 0.15$ & $5.07^{\mathrm{c}} \pm 0.02$ & $2995^{\mathrm{a}} \pm 4.08$ \\
LSD & 0.0199 & - & - & 0.0663 & 19.56 \\
\hline
\end{tabular}

Mean \pm standard deviation of triplicate determination. Means with the same superscripts a column are not significantly different $(\mathrm{P} \leq 0.05)$. $\mathrm{W}_{1}=$ Wheat flour $(100 \%)$

$\mathrm{MW}_{1}=$ Watermelon seed meal/wheat flour (10:90)

$\mathrm{MW}_{2}=$ Watermelon seed meal/wheat flour (20:80)

$\mathrm{MW}_{3}=$ Watermelon seed meal/wheat flour (30:70)

$\mathrm{MW}_{4}=$ Watermelon seed meal/ wheat flour (40:60)

$\mathrm{MW}_{5}=$ Watermelon seed/wheat flour (50:50)

Chinma and Gernah (2001) observed a similar trend in cookies produced from cassava/ soya/mango composite flour and attributed it to the hydrophilic nature of the flour used in the products which led to decrease in spread ratio and increase in thickness. It was observed that $\mathrm{MW}_{3}$, which had the least spread ratio, also had the highest thickness.

No significant difference occurred within the samples. Ade et al. (2012), noted that when a dough or batter becomes less viscous, it tends to spread more thereby increasing in diameter and consequently the spread factor. Again the biscuit sample with the highest spread ratio $\left(\mathrm{MW}_{2}\right)$ also had the highest diameter.

$\mathrm{W}_{1}$ (6.24) was found to be highest in weight while $\mathrm{MW}_{5}(5.22)$ had the least. No significant difference occurred among the samples, however, the weight decreased with higher percentage substitution with watermelon seed meal. Helen and Ndidiamaka (2014) observed similar trend in cookies produced from wheat/beniseed/unripe plantain flours and attributed it to higher contents of starch and low crude fibre in wheat than unripe plantain and beniseed. It was also observed that the trend in weight was similar to the result of bulk density (Table 2) and crude fibre content (Table 4).

The result obtained from break strength showed that $\mathrm{MW}_{5}(2995 \mathrm{~g})$ had the highest value while $\mathrm{W}_{1}(1400 \mathrm{~g})$ had the least. Biscuit samples from composite flours were very hard and lacked the characteristic quality of biscuit due to the absence of fat in their recipe; as fat plays a major role in determining texture as well as rheology and overall quality of product (Ubbor and Akobundu, 2009). Though watermelon seed meal substituted fat in the biscuits, however, from the observation, small amount of fat should be added to aid that from the watermelon seed to be able to get the characteristic quality needed.

\subsection{Sensory Qualities}

The sensory evaluation scores of biscuit samples are shown in Table 6. There were significant differences $(\mathrm{p} \leq 0.05)$ among the biscuit samples in the parameters evaluated. Biscuits made from wheat flour $(100 \%)$ were significantly different from the biscuits made from composite flour samples except in colour and crispiness. The non-inclusion of fat in the recipe of composite flour samples affected biscuits made from them in taste, aroma, texture and overall acceptability as fat is an important factor which helps in improving flavour and mouthfeel and contributes to the appearance, palatability and texture of biscuits (Sushma et al., 2016).

No significant difference occurred among the composite biscuit samples, however, biscuits from $\mathrm{MW}_{1}(6.05)$ received a higher score in aroma and overall acceptability.

Colour is an important sensory attribute of any food because of its influence on acceptability. The brown colour resulting from Maillard reaction is always associated with baked goods (Ubbor and Akobundu, 2009). Biscuit samples from $M_{1}$ was not significantly different from that of $W_{1}$, likewise $M_{2}$ and $M_{3}$ while $M_{4}$ and $\mathrm{MW}_{5}$ were each significantly different $(\mathrm{p} \leq 0.05)$ from the rest of the samples respectively. 
Table 6. Sensory Evaluation Scores of Biscuits

\begin{tabular}{lllllll}
\hline \multicolumn{5}{c}{ Parameter } \\
\hline Sample & Taste & Aroma & Colour & Texture & Crispiness & Overall acceptance \\
\hline $\mathrm{W}_{1}$ & $7.70 \mathrm{a} \pm 1.01$ & $7.20 \mathrm{a} \pm 1.03$ & $6.30 \mathrm{~d} \pm 1.58$ & $6.45 \mathrm{~d}+1.02$ & $6.85 \mathrm{ab} \pm 1.24$ & $7.75 \mathrm{a} \pm 0.94$ \\
$\mathrm{MW}_{1}$ & $5.50 \mathrm{~b} \pm 1.29$ & $6.05 \mathrm{~b} \pm 0.97$ & $6.50 \mathrm{~d} \pm 0.50$ & $6.90 \mathrm{c}+1.09$ & $7.35 \mathrm{a} \pm 1.28$ & $6.05 \mathrm{~b} \pm 1.07$ \\
$\mathrm{MW}_{2}$ & $5.85 \mathrm{~b} \pm 1.42$ & $5.40 \mathrm{~b} \pm 1.28$ & $7.20 \mathrm{c} \pm 0.91$ & $7.60 \mathrm{~b}+0.92$ & $5.0 \mathrm{~d} \pm 0.95$ & $5.80 \mathrm{~b} \pm 1.72$ \\
$\mathrm{MW}_{3}$ & $5.70 \mathrm{~b} \pm 1.82$ & $5.50 \mathrm{~b} \pm 1.53$ & $7.40 \mathrm{c} \pm 0.80$ & $7.85 \mathrm{~b}+0.73$ & $7.45 \mathrm{a} \pm 1.28$ & $6.00 \mathrm{~b} \pm 1.30$ \\
$\mathrm{MW}_{4}$ & $5.65 \mathrm{~b} \pm 1.59$ & $5.25 \mathrm{~b} \pm 1.70$ & $8.10 \mathrm{~b} \pm 0.62$ & $8.00 \mathrm{ab}+1.05$ & $6.05 \mathrm{bc} \pm 1.75$ & $5.60 \mathrm{~b} \pm 1.28$ \\
$\mathrm{MW}$ & $5.90 \mathrm{~b} \pm 1.58$ & $5.20 \mathrm{~b} \pm 1.75$ & $8.70 \mathrm{a} \pm 0.48$ & $8.35 \mathrm{a}+0.73$ & $5.7 \mathrm{~cd} \pm 1.38$ & $5.75 \mathrm{~b} \pm 1.34$ \\
$\mathrm{LSD}$ & 0.946 & 0.906 & 0.577 & 0.420 & 0.856 & 0.761 \\
\hline
\end{tabular}

Mean \pm Standard deviation of sensory evaluation score.

Means with the same superscripts within a column are not significantly different $(\mathrm{P} \leq 0.05)$

$\mathrm{W}_{1}=$ Wheat flour $(100 \%)$

$\mathrm{WM}_{1}=$ Watermelon seed meal/wheat flour (10:90)

$\mathrm{MW}_{2}=$ Watermelon seed meal/wheat flour $(20: 80)$

$\mathrm{MW}_{3}=$ Watermelon seed meal/wheat flour (30:70)

$\mathrm{MW}_{4}=$ Watermelon seed meal/wheat flour (40:60)

$\mathrm{MW}_{5}=$ Watermelon seed meal/wheat flour (50:50)

This result showed increase in brown colour with higher substitution with toasted watermelon seed meal and could obviously be attributed to brown colour effect of watermelon seed meal.

$\mathrm{MW}_{5}$ was significantly different $(\mathrm{p} \leq 0.05)$ in texture with values ranged from 6.45 to $8.35 . \mathrm{MW}_{5}$ and $\mathrm{MW}_{4}$ were not significantly different, likewise $\mathrm{MW}_{2}, \mathrm{MW}_{3}$ and $\mathrm{MW}_{4}$. The texture was strong and firm in composite biscuit samples with increase in substitution. This observation could be due to the non-inclusion of fat in the composite biscuit recipe as fats help to lubricate, weaken, or shorten the structure of food components to provide a food product with desirable textural properties (Hasmadi and Sandra, 2014).

Crispiness is a desired quality of biscuits. Significant difference $(\mathrm{p} \leq 0.05)$ existed among the biscuit samples. With respect to overall acceptability, $\mathrm{W}_{1}(100 \%$ wheat flour $)$ was most preferred. Significant difference $(\mathrm{p} \leq 0.05)$ occurred between $100 \%$ wheat flour biscuit samples and composite flour biscuit samples. $\mathrm{W}_{1}$ was significantly different from the other samples. No significant difference among biscuit samples from composite flour blends even though $\mathrm{MW}_{1}$ (6.05) and $\mathrm{MW}_{3}$ (6.0) received higher scores respectively.'

\subsection{Storage Study (Microbial Count And Moisture Absorption)}

Total viable count reflects the conditions in which the food was produced, stored, or abused during handling and can be used to predict the shelf life or keeping quality of the product. The spoilage of many foods may be imminent when the total viable count reaches from 10 - 100 million per gram of the product (Nagi et al., 2012). The total microbial load on nutrient agar for bacteria and Potato-dextrose agar for fungi were $2.0 \times 10^{2} \mathrm{cfu} / \mathrm{g}$ and $1.8 \times 10^{1} \mathrm{cfu} / \mathrm{g}$ for $\mathrm{MW}_{1}$ and $2.8 \times 10^{2} \mathrm{cfu} / \mathrm{g}$ and $2.7 \times 10^{1} \mathrm{cfu} / \mathrm{g}$ for $\mathrm{MW}_{3}$ respectively in week one.

Almost all microorganisms were destroyed during baking due to high temperature. But during packaging, cross contamination could occur due to handling of biscuits. Bacteria usually require at least 0.91 water activity $\left(\mathrm{a}_{\mathrm{w}}\right)$, and fungi require at least $0.7 \mathrm{a}_{\mathrm{w}}$, while below $0.6 \mathrm{a}_{\mathrm{w}}$, microorganisms cannot survive (Pupulawaththa et al., 2014).Total microbial load increased in week 3. The result in Table 4.6 also indicated that biscuits absorbed moisture during the period of storage.

Table 7. Total Viable Counts of Bacteria and Mould from the Accepted Blends of Biscuits Stored For 6 Weeks and the \%Moisture Content

\begin{tabular}{|c|c|c|c|c|c|c|c|}
\hline \multirow[t]{2}{*}{ Sample code } & \multirow[t]{2}{*}{ Types of organism } & \multicolumn{3}{|c|}{ Storage time (weeks) } & \multicolumn{3}{|c|}{$\%$ moisture absorbed in 6 weeks } \\
\hline & & 0 & 3 & 6 & 0 & 3 & 6 \\
\hline $\mathrm{MW}_{1}$ & Bacteria & $2.0 \times 10^{2}$ & $5.2 \times 10^{5}$ & $5.1 \times 10^{7}$ & 6.25 & 11.75 & 13.25 \\
\hline $\mathrm{MW}_{3}$ & & $2.8 \times 10^{2}$ & $6.8 \times 10^{5}$ & $6.3 \times 10^{7}$ & 6.75 & 11.00 & 12.00 \\
\hline $\mathrm{MW}_{1}$ & Mould & $1.8 \times 10^{1}$ & $6.1 \times 10^{3}$ & $2.8 \times 10^{5}$ & 6.25 & 11.75 & 13.25 \\
\hline $\mathrm{MW}_{3}$ & & $2.7 \times 10^{1}$ & $7.4 \times 10^{3}$ & $4.0 \times 10^{5}$ & 6.75 & 11.00 & 12.00 \\
\hline
\end{tabular}

$\mathrm{WM}_{1}=$ Watermelon seed meal/wheat flour (10:90)

$\mathrm{WM}_{2}=$ Watermelon seed meal/wheat flour (30/70)

The gain in moisture might be due to hydroscopic nature of dried products, storage environment (temperature and relative humidity) as well as the nature of packaging material (Nagi et al., 2012). The increase in microbial 
load as the storage period lengthened might have been due to a corresponding increase in moisture contents during storage and availability of nutrient in the biscuits.Also, there was no addition of preservative to inhibit microbial growth, low acid nature of biscuit and low level of antimicrobial activities of watermelon seed extract (Braide et al., 2012) may have contributed an increase of the microbial load. The percentage moisture absorbed ranged from $6.25 \%$ (zero) to $11.75 \%, \mathrm{MW}_{1}$ absorbed the highest moisture and was also the most crispest biscuit amongst all.

\section{Conclusion}

The results of the functional properties of the flour blends showed that the composite flour blends could be suitable for biscuit production and other food formulations.

The research has also revealed that the proximate composition of biscuits produced from the composite flour blends are better, compared to that made solely from wheat flour and hence toasted watermelon seed meal can be incorporated up to $30 \%$ substitution level based on the sensory score. Biscuits prepared from such composite flour could help in combating protein-energy malnutrition; have the potential as a functional food especially for coeliac, diabetic, obese and heart disease patients in view of their high protein, crude fibre, and ash contents, with low fat and carbohydrate contents than $100 \%$ wheat flour biscuits.

\section{References}

Abbey, B. W., \& Ibeh, G. O. (1998). Functional Properties of Raw ande Heat Processed Cowpea (Vignaunguiculata, walp) flour. Journal of Food Science, 5(6), 1775-1777. https://doi.org/10.1111/j.1365-2621.1988.tb07840.x

Ade, J. C., Ingbian, E. K., \& Abu, J. O. (2012). Physical Chemical and sensory properties of baked products from bean (Sphenostylisstenocarpa) water-Extractable proteins. Nigeria Food Journal, 30(1), 109-115. https://doi.org/10.1016/S0189-7241(15)30019-9

AOAC (2000). Official methods of analysis (17th edn.). Association of official analytical chemist. Washington, DC, USA.

Ayo, J. A., \& Olawale, O. (2003). Effect of defaulted groundnut concentrate on the physiochemical and sensory quality of "Fuva". Nutrition and Food Science, 33(4), 175-183. https://doi.org/10.1108/00346650310488525

Ayo, J. A., Ayo, V. A., Nkama, I., \& Adeworie, R. (2007). Physiochemical, InvitroDigestibility and Organoleptic Evaluation of Acha-wheat BiscuitSupplemented with Soybean flour. Niger. Food J.

Banureka, V. P., \& Mahendran, T. (2009). Formulation of wheat-soybean biscuits and their quality characteristics. Tropical Agricultural Research and Extension, 12(2), 62-66. https://doi.org/10.4038/tare.v12i2.2791

Bhawna, C., Gurmukh, S., \& Kumbhar, B. K. (2013). Development of low fat soft Dough Biscuits Using Carbohydrate-Based Fat Replacers. International Journal of Food Science.

Boobier, W. J., Baker, J. S., \& Davies, B. (2006). Development of a healthy biscuit: an alternative approach to biscuit manufacture. Nutritional Journal, 5(7). https://doi.org/10.1186/1475-2891-5-7

Braide, W., Odiong, I. J., \& Oranusi, S. (2012). Phytochemical and antibacterial properties of the seed of watermelon (Citrulluscanatus). Prime Journal of Microbiology Research, 2(3), 99-104.

Brandt, L. (1996). Emulsifiers in Baked Goods. Food Product Design. Virgo Publishing, USA, pp96

Chinma, C. E., \& Gernah, D. T. (2001). Physicochemical and ssnesory properties of cookies produced from cassava/soyeabean/mango composite flours. Journal of Raw Material and Research, 4, 32-43.

El-Adawy, T. A., \& Taha, K. M. (2001). Characteristics and composition of watermelon, pumpkin and paprika seed oils and flours. Journal of Food Chemistry, 49(3), 1253-1259. https://doi.org/10.1021/jf001117+

Erhirhie, E. O., \&Ekene, N. E. (2013). Medicinal values on citrulluslanatus (watermelon): pharmacological review. International Journal of Research in Pharmaceutical and Biomedical Sciences, 4(4), 1305-1312.

Gomez, M. I., Obilance, A. B., Martin, D. F., Madzvanuse, M., \& Many, E. S. (1997).Manual of Laboratory Procedures for quality evaluation of sorghum and Millet. International crop Research Isntitute of the Semi-Arid and Tropics (ICRSAT), India P.64.

Hasmadi, M., Patricia, M., Salwa, J., Siti, F., Mansoor, A., \& Ainnor, S. (2014). The effect of seaweed composite flour on the textural properties of dough and bread. Journal of Applied Physiology, 26(2).

Helen, O. A., \& Ndidiamaka, A. O. (2014). Physico-chemical, sensory, and microbiological assessments of 
wheat-based biscuit improved with beniseed and unripe plantain.Food Science and Nutrition, 2(5), 464-469. https://doi.org/10.1002/fsn3.135

Ihekoronye, A. I., \& Ngoddy, P.O. (1985). Organoleptic Qualities of foods. In: Integrated Food Science and Technology for the Tropics. Macmillan Publ. Hong Kong.194-206.

Maziya-Dixon, B., Dixon, A. G. O., \& Adebowale, A. A. (2007). Targeting different and uses of cassava: genotypic variations for cyanogenic potentials and pasting properties. International Journal of Food Science Technology, 42, 969-976. https://doi.org/10.1111/j.1365-2621.2006.01319.x

Mensink, R. P., \&Katan, M. B. (1987). Effect of monounsaturated fatty acids versus complex carbohydrates on high-density lipoproteins in healthy men and women.lancet, 1, 122-125. https://doi.org/10.1016/S0140-6736(87)91965-9

Mervat, E. (2011). Evaluation of physico-chemical properties of toast breads fortified with pumpkin (Cucurbitamoschata) flour. In the 6th Arab and $3^{\text {rd }}$ international Annual Scientific Conference Egypt

Miller, R. A., Hoseney, R. C., \& Morris, C. F. (1997). Effect of formula water content on the spread of sugar-snap cookies. Cereal Chemistry, 74, 669-671. https://doi.org/10.1094/CCHEM.1997.74.5.669

Mooriya, G. T. (2003). Traditional methods of production of high protein energy foods from grain legumes in the North-Estern states of Nigeria. Annals of Appl. Nutri., 43, 238-247.

Nagi, H. P. S., Kaur, J., Dav, B. N., \& Sharma, S. (2012). Effect of storage period and packaging on the shelf life of cereal Bran incorporated Biscuits. American Journal of Food Technology, 7, 301-310. https://doi.org/10.3923/ajft.2012.301.310

Nisbett, E. F., Rossiter, A. H., Miller, A. R., \&Thacker, O. (1986). Eat in short dough biscuits. Flour Milling and Baking Research Association Bulletin (FMBRA), 2, 63-77.

O'brien, R. D. (2003). Fats and Oils: Formulating and processing for applications, CRC Press, Boca Roton, Fla, USA. https://doi.org/10.1201/9780203483664

Obatolu, V. A., Fusoyiro, S. B., \&Ogunsunmi, L. O. (2008). Processing and functional properties of yam beans (Sphenotylissternocarpa). Journal of Food Processing and preservation, 31, 240-249. https://doi.org/10.1111/j.1745-4549.2007.00112.x

Odibo, F. J. C., Nwabunnia, E., Ezekwegbu, C. C., \& Uzoghe, E. (2012). Fermentation of Cucumeropsis seeds, an uncommon substrate for ogiri production. African Journal Microbiol Research, 6(24), 5095-5099.

Okaka, J. C., \& Isieh, M. I. (1990). Development and Quality evaluation of Cowpea-wheat biscuit. Nigerian Food Journal, 8, 56-62.

Okpala, L. C., \& Egwu, P. N. (2015). Utilization of broken rice and cocoyam flour blends in the production of biscuit. Nigerian food Journal, 33(1), 8-11. https://doi.org/10.1016/j.nifoj.2015.04.010

Oluwalana, I. B., \& Oluwamukomi, M. O. (2011). Proximate composition, rheological and sensory qualities of plantain (Musa parasidiaca) flour blanched under three temperature regime. African Journal of Food Science, 5, 769-774. https://doi.org/10.5897/AJFS11.118

Onwuka, G. I. (2005). Food Analysis and Instrumentation, Theory and Practice. Naphtali Prints, Suruleve, Lagos. 63-75.

Oti, E., \& Akobundu, E. N. T. (2008). Physiochemical and functional properties of some cultivars of cassava. Nigerian Agricultural journal, 39(1\&2), 137-145

Pupulawaththa, A. W., Perera, O. D. A. N., \& Ranwala, A. (2004). Development of fibre Rich Soft Dough Biscuits fortified with Kohila (Lasiaspinosa) flour. Journal of Food Processing Technology, 5, 395.

Robert, J. S. (2008). Dietary Determinants of Obesity. The Concise Oxford Dictionary.

Roberts, G., \& Greenwood, M. (2003). Practical Food microbiology, $3^{\text {rd }}$ Edn., Blackwell Publishing, Massachusetts USA, pp 105-110.

Singh, U. (2001). Functional properties of grain legumes flours. Journal of food science, 38, 191-199.

Smith, W. H. (1972). Biscuits, Crackers and Cosicies: Technology, production and managementBaking: Applied Science.

Sushma, T., Beenu, T., Ambike, C., \& Vikas, K. (2016). Physicochemical andorganoleptic properties of cookies incorporated with legumes flours. Congent Food and Agriculture, 2(1). 
Ubbor, S. C., \& Akobundu, E. N. T. (2009). Quality characteristics of cookies from composite flour of watermelon seed, cassava and wheat. Pakistan Journal of Nutrition, 8, 1097-1102. https://doi.org/10.3923/pjn.2009.1097.1102

Ukpabi, U. J., \& Ndimele, C. (1990). Evaluation of gari production in Imo State Nigeria. Nigerian Food Journal, $8,105-110$

Willet, W. C., Stampfer, M. J., \&Manson, J. E. (1993). Intake of Tran's fatty acids and risk of coronary heart disease among women. Lancet, 341, 581-585. https://doi.org/10.1016/0140-6736(93)90350-P

Yahya, M. N. (2004). Physicochemical and shelf life studies on reduced fat legume-based cookies using sago flour as a fat replacer (Msc. Thesis).

\section{Copyrights}

Copyright for this article is retained by the author(s), with first publication rights granted to the journal.

This is an open-access article distributed under the terms and conditions of the Creative Commons Attribution license (http://creativecommons.org/licenses/by/4.0/). 